Ulumuddin: Jurnal Ilmu-ilmu Keislaman

(p)ISSN: 1907-2333 (e)ISSN: 2685-9211

https://jurnal.ucy.ac.id/index.php/agama_islam

Volume 10 Nomor 1, Juni 2020, 71-85

\title{
Pengaruh Hidden Curriculum dan Disiplin Terhadap Religiusitas Siswa SMPN 1 Mlarak Ponorogo
}

\begin{tabular}{|c|c|c|}
\hline \multicolumn{3}{|c|}{$\begin{array}{l}\text { Ihwan Mahmudi }{ }^{*} \text { ), Taufik Abdullah Attamimi²) } \\
\text { 1,2)Universitas Darussalam Gontor } \\
\text { ihwanm@unida.gontor.ac.id'1), taufik.attd@gmail.com²) }\end{array}$} \\
\hline \multicolumn{3}{|c|}{${ }^{*}$ Penulis koresponden } \\
\hline Diajukan: 16-05-2020 & Diterima: $15-06-2020$ & Diterbitkan: 19-06-2020 \\
\hline
\end{tabular}

\begin{abstract}
This research aims to determine the effect of hidden curriculum and discipline on student religiosity. This research approach uses a quantitative approach with questionnaire survey methods. Sampling uses simple random sampling from an affordable population, namely class VIII students who are part of the target population, namely all students of SMPN 1 Mlarak Ponorogo. The sample of this study was 114 out of 170 students. Data analysis techniques using descriptive analysis, prerequisite tests, and hypothesis testing using multiple regression analysis of two predictors. The results of the $\mathrm{H} 1$ study with a calculated $\mathrm{t}$ value of 2,404 and sig. $0.010 / 2=0.005(\mathrm{p}<0.05)$, Ho is rejected which means that there is an influence of hidden curriculum on religiosity. $\mathrm{H} 2$ with a value of $\mathrm{t}$ count 1.944 and sig. $0.054 / 2=0.027$ ( $\mathrm{p}<0.05)$, Ho is rejected which means there is a disciplined influence on religiosity. And $\mathrm{H}_{3}$ with an $\mathrm{F}$ value of 27.095 and sig. 0.000 ( $\left.\mathrm{p}<0.05\right)$, Ho is rejected which means that there is a hidden influence of the curriculum and discipline simultaneously on the religiosity of students of SMPN 1 Mlarak Ponorogo.
\end{abstract}

Keywords: Religiosity, hidden curriculum, Disiplin

Abtrak: Tujuan penelitian ini mengetahui pengaruh hidden curriculum dan disiplin terhadap religiuistas baik secara parsial maupun simultan. Pendekatan penelitian ini menggunakan pendekatan kuantitatif dengan metode survey melalui angket. Pengambilan sampel menggunakan simple random sampling dari populasi terjangkau yaitu siswa kelas VIII yang merupakan bagian dari populasi target yaitu seluruh siswa SMPN 1 Mlarak Ponorogo. Sampel penelitian ini berjumlah 114 dari 170 siswa. Data dianalisa menggunakan analisis deskriptif, uji prasyarat, dan uji hipotesis dengan analisis regresi ganda dua prediktor. Hasil penelitian $\mathrm{H} 1$ dengan nilai t hitung 2.404 dan sig. $0.010 / 2=0.005(\mathrm{p}<0.05)$, Ho ditolak yang berarti terdapat pengaruh hidden curriculum terhadap religisuitas. H2 dengan nilai t hitung 1.944 dan sig. $0.054 / 2=0.027(\mathrm{p}<0.05)$, Ho ditolak yang berarti terdapat pengaruh disiplin terhadap religiusitas. Dan $\mathrm{H}_{3}$ dengan nilai $\mathrm{F}$ hitung 27.095 dan sig. 0.000 ( $\mathrm{p}<0.05$ ), Ho ditolak yang berarti terdapat pengaruh hidden curriculum dan disiplin secara simultan terhadap religiusitas siswa SMPN 1 Mlarak Ponorogo.

Kata Kunci: Religiusitas, hidden curriculum, Disiplin 


\section{A. Pendahuluan}

Salah satu karakter yang terpenting adalah religiusitas sebagai kebutuhan dan patokan dalam kehidupan manusia. Di Indonesia, termasuk dalam 18 karakter yang harus dimiliki oleh anak bangsa. ${ }^{1}$ Islam pun telah memprioritaskan pendidikan karakter religius bagi umatnya. ${ }^{2}$

Penghayatan karakter Islam berkebangsaan bahkan sudah biasa di pesantren Indonesia.3 Pendidikan demikian ini tidak bisa terlepas dari kekuatan hubungan guru dan siswa baik secara formal maupun nonformal,4 terutama dengan Guru Pendidikan Agama.5 Hal itu bisa didukung dengan komponen lainnya agar karakter religiusitas bisa berdampak pada kehidupan peserta didik sekarang hingga kelak.

Melalui wawancara bapak Zaenal Abidin, guru Pendidikan Agama Islam SMPN 1, beberapa upaya telah diambil sekolah guna pengembangan religiusitas siswa. Penguatan organisasi budaya disiplin telah dilakukan.

SMPN 1 pun menerapkan hidden curriculum melalui pembiasaan beribadah dan kegiatan keagamaan lainnya di sekolah secara konsisten. Kepentingannya diterapkankan karena seluruh kegiatan siswa pasti berkaitan. Persandingan hidden curriculum terjadi baik itu di kelas maupun di luar kelas meski tidak secara formal tertulis dalam tujuan pendidikan. 6

1 Pusat Kurikulum Kemendiknas, Pendidikan Budaya dan Karakter Bangsa (Jakarta: Kemendiknas, 2010), 3.

2 Taufik Nugroho, "Pendidikan Karakter Dalam Al-Qur'an (Studi Tafsir Pendidikan Surat Luqman)," Ulumuddin Jurnal Ilmu-ilmu Keislaman 4, no. 1 (2014): 14-22.

3 Taufik Nugroho, "Ideologi Pendidikan Pondok Pesantren Al-Islam Tenggulun Solokuro Lamongan," Ulumuddin: Jurnal Ilmu-ilmu Keislaman 9, no. 2 (2020): 97-112; Umi Musaropah, "Pendidikan Kebangsaan Dalam Pesantren Perspektif Abdul Wahid Hasyim," Ulumuddin: Jurnal Ilmu-ilmu Keislaman 9, no. 1 (2019): 1-22.

4 Nurul Fatihah dan Difla Nadjih, "Hubungan Pendidik Dan Terdidik Dalam AlQuran,” Ulumuddin: Jurnal Ilmu-ilmu Keislaman 7, no. 2 (2017): 73-86.

5 Rozib Sulistiyo, "Penguatan Peran Guru Pendidikan Agama Islam Dalam Penanaman Akhlak Di Sekolah," Ulumuddin: Jurnal Ilmu-ilmu Keislaman 6, no. 1 (2016): 1-10.

6 Caswita, The Hidden Curriculum: Studi Pembelajaran PAI di Sekolah (Yogyakarta: Leutikaprio, 2013), 45. 


\section{Pengaruh Hidden Curriculum dan Disiplin Terhadap}

Religiusitas Siswa SMPN 1 Mlarak Ponorogo

Beberapa penelitian relevan dilakukan. diantaranya oleh Pratiwi di salah satu SMP Islam swasta di Yogyakarta.7 Palupi mengaitkannya dengan kenakalan remaja di SMP Negeri Tegal. ${ }^{8}$ Penelitian ini bertujuan untuk mengetahui pengaruh hidden curriculum dan disiplin terhadap religiusitas siswa SMP Negeri baik secara simultan maupun parsial.

\section{B. Tinjauan Literatur}

1. Religiusitas

Religiusitas secara etimologi berasal dari kata religi. Menurut Drikarya, berarti mengikat, yang mempunyai maksud suatu kewajiban dan aturan aturan yang harus dilaksanakan, yang berfungsi sebagai cara mengikat dan mengukuhkan diri baik seseorang atau kelompok dalam hubungan dengan alam sekitar, manusia, dan Tuhan. ${ }^{9}$ Dalam bahasa berbeda, Sudarso menjelaskan Agama religi berupa peraturan dari Tuhan yang mempunyai dimensi vertical dan horizontal dan mampu memberikan dorongan terhadap jiwa manusia, yang dapat dijadikan pedoman dengan kehendaknya sendiri, tanpa dipengaruhi, bagi pencapaiannya terhadap kebahagiaan dunia dan akhirat kelak. ${ }^{10}$

Religiusitas sendiri merupakan sikap dan perilaku patuh terhadap ajaran agama yang dianutnya, toleran dengan agama lain, dan hidup rukun dengan pemeluk agama lain. ${ }^{11}$ Ancok dan Suroso menunjukkan perwujudannya di berbagai sisi kehidupan manusia. ${ }^{12}$ Semua perilaku yang dilakukan merupakan aplikasi dari religiusitas, termasuk yang nampak maupun tidak nampak, sehingga keberagamaan seseorang dapat timbul dalam berbagai dimensi. ${ }^{13}$

7 Esti Rahma Pratiwi, "Pengaruh Kurikulum Tersembunyi (Hidden Curriculum) Terhadap Pembentukan Karakter Siswa Kelas VIII Di SMP IT Masjid Syuhada' Kotabaru Yogyakarta” (UIN Sunan Kalijaga, 2016).

8 Atika Oktaviana Palupi, "Pengaruh Religusitas Terhadap Kenakalan Remaja Pada Siswa Kelas VIII SMP Negeri 02 Slawi Kabupaten Tegal” (Universitas Negeri Semarang, 2013).

9Ari Widiyanta, “Sikap Terhadap Lingkungan Dan Religiusitas,” Jurnal Pemikiran Dan Penelitian Psikologi 1, no. 2 (2005), 80.

10 Sudarsono, Kenakalan remaja (Jakarta: Rineka Cipta, 2008), 119.

11 Muhammad Yaumi, Pendidikan Karakter, (Landasan, Pilar, Dan Implementasi) (Jakarta: Kencana, 2014), 85.

12 Djamaluddin Ancok dan Fuad Nashori Suroso, Psikologi Islam Solusi Islam atas Problem Problem Psikologi (Yogyakarta: Pustaka Pelajar, 1995), 76.

13 Palupi, "Pengaruh Religusitas," 36-37 
Religiusitas Islam memiliki dimensi keyakinan (Aqidah), Praktik Agama (Syariah), Pengalaman (Penghayatan), Pengetahuan Agama (Ilmu), dan Pengamalan Atau Konsekuensi (Akhlaq). Dimensi keyakinan atau aqidah mencakup keyakinan kepada Allah, malaikat Allah, kitab kitab allah, nabi atau rasul Allah, kepada hari akhir (adanya neraka dan syurga), kepada qadha dan qadar. ${ }^{14}$ Dimensi Praktik Agama (Syariah) mencakup sholat, puasa, zakat, membaca Al qur'an, dzikir dan do'a, ibadah qurban, i’tikaf di masjid di bulan suci ramadhan, dan lain sebagainya. 15

Dimensi penghayatan mencangkup perasaan dekat dengan Allah, perasaan terkabulnya doa, hidup terasa tentram dan bahagia dengan percaya kepada Allah, perasaan tawakal kepada Allah, perasaan khusuk saat shalat dan berdo'a, bergetar mendengarkan ayat Qur'an, bersyukur, perasaan mendapat pertolongan Allah. ${ }^{16}$ Dimensi Pengetahuan Agama (Ilmu) mencangkup pengetahuan tentang Al- Quran, dan pengetahuan aqidah Islam, hukum islam, sejarah islam, dan lain sebagainya. ${ }^{17}$ Sedangkan Dimensi Pengamalan (Akhlaq) meliputi perilaku suka menolong, kerjasama, menegakkan keadilan dan kebenaran, bersikap jujur, memaafkan, menjaga lingkungan hidup, tidak korupsi, tidak menipu, tidak berjudi, tidak meminum yang memabukkan, dan sebagainya. ${ }^{18}$

Religiusitas menjadi merupakan suatu gambaran yang terdapat kepada diri seseorang yang mempengaruhi perilaku, sikap maupun tindakan, sesuai dengan agama yang dianutnya. Religiusitas lebih condong ke aspek kualitas manusia dalam beragama.

2. hidden curriculum

Hidden curriculum diartikan sebagai, "hasil (sampingan) dari pendidikan dalam sekolah atau luar sekolah, khususnya hasil yang

14 Din Zainuddin, Pendidikan Budi Pekerti Dalam Perspektif Islam (Jakarta: Al Mawardi Prima, 2005), 35- 86.

${ }^{15}$ Ancok dan Suroso, Psikologi Islam, 80.

${ }^{16}$ Ibid., 82

17 Ibid.

18 Ibid. 


\section{Pengaruh Hidden Curriculum dan Disiplin Terhadap}

Religiusitas Siswa SMPN 1 Mlarak Ponorogo

dipelajari tetapi tidak secara tersurat dicantumkan sebagai tujuan."19 Kurikulum tersembunyi itu tidak direncanakan dan tidak muncul di kurikulum formal, tetapi memiliki pengaruh penting dalam kehidupan siswa. ${ }^{20}$ Termasuk di dalamnya komponen sekolah dalam hubungan interaksi vertical dan horizontal berupa lingkungan sekolah, suasana kelas, pola interaksi guru dengan siswa, bahkan kebijakan serta manajemen pengelolaan sekolah. ${ }^{21}$ Glattron telah menunjukkan pengaruhnya terhadap perubahan nilai, persepsi, dan perilaku siswa. ${ }^{22}$

Dua dimensinya, yaitu: 1) structural yang berkaitan dengan struktural ini meliputi tentang pembagian kelas, berbagai kegiatan ekstra kulikuler, berbagai fasilitas yang ada disekolah seperti fasilitas olahraga, buku teks, fasilitas multimedia, perpustakaan laboratorium, tempat ibadah. 2) kultural yang meliputi norma, etos kerja, peran dan tanggung jawab, relasi antar pribadi dan kelompok, konflik antar pelajar, ritual dan perayaan ibadah, kerja sama, kompetisi serta disiplin waktu.

3. Disiplin

Secara bahasa disiplin berasal dari bahasa Latin yaitu discrere yang mempunyai arti berawal dari kita, yang kemudian menjadi diclipina yang mempunyai arti latihan. ${ }^{23}$ Sedangkan dalam Kamus Besar Bahasa Indonesia, disiplin berarti tata tertib, ketaatan atau system.

Di Stevenson, disiplin itu usaha yang timbul dari diri seseorang berupa pengontrolan diri menghasilkan sesuatu dengan seluruh daya dan upaya tanpa adanya suruhan dalam melakukannya. ${ }^{24}$ Menurut Tu'u, upaya untuk mengendalikan diri dan sikap mental individu dalam mengembangkan kepatuhan terhadap tata tertib berdasarkan kesadaran

19 Syarifah, Managemen Pengelolaan Lembaga Pendidikan (Ponorogo: Unida Gontor Press, 2018).

2o Oemar Hamalik, Dasar Dasar Pengembangan Kurikulum (Bandung: Remaja Rosda Karya, 2009), 23.

${ }^{21}$ Dede Rosyada, Paradigma Pendidikan Demokratis (Jakarta: Kencana Prenada Media Group, n.d.), 31.

${ }^{22}$ Caswita, The Hidden Curriculum, 45.

23 Neiny Ratmaningsih, Pendidikan Pancasila dan kewarganegaraan untuk SMU kelas 1 (Bandung: Grafindo Media Pratama, 2000), 58.

24 Ibid., 92 
dari hatinya.25 Disiplin itu juga menjadi patokan seperti yang diutarakan oleh Arikunto. Disiplin adalah tingkat kepatuhan seseorang dalam menjalankan tata tertib karena kesadaran dalam hatinya. ${ }^{26}$

Disiplin demikian menjadi serangkaian perilaku yang muncul dari dalam diri seseorang untuk menunjukkan kepatuhan dan ketaatan terhadap tata tertib dalam mencapai tujuan yang diinginkan. Imas Kurinasih Dan Berlin Sani mengindikasikannya dalam perilaku berupa datang tepat waktu, patuh pada tata tertib atau aturan bersama/ sekolah, mengerjakan tugas sesuai dengan waktu yang ditentukan, dan mengikuti kaidah berbahasa tulis yang baik dan benar. ${ }^{27}$

\section{Metode}

Penelitian ini menggunakan pendekatan kuantitatif,28 namun tidak dalam bentuk penelitian tindakan kelas (PTK).29 Yang terpilih adalah survey berangket. Analisis data kemudian menggunakan analisis regresi ganda. Desain penelitian adalah seperti gambar berikut:

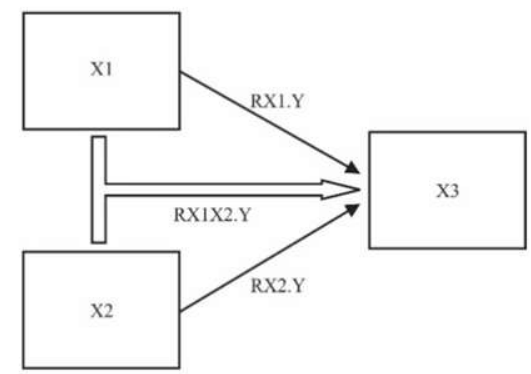

Sampel penelitian berjumlah 114 siswa kelas VIII siswa SMPN 1 berdasar teknik simple random sampling. Angket kemudian terlebih dahulu diuji validitas dan reliabilitasnya. Teknik analisis data terdiri; analisis deskriptif, uji persyaratan analisis dan uji hipotesis.

\section{Hasil Penelitian}

${ }_{25}$ Feri Sulis Diana, Setyorini, and Sapto Irawan, "Pengaruh Nilai Pendidikan Karakter Terhadap Disiplin Siswa Kelas XI SMK Islam Sudirman Tahun Ajaran 2018/2019," Jurnal Psikologi Konseling 12, no. 1 (2019): 373-386.

${ }^{26}$ Suharsimi Arikunto, Managemen Penelitian (Jakarta: Rineka Cipta, 2001), 114.

27 Imas Kurinasih dan Berlin Sani, Implementasi Kurikulum 2013 Konsep Dan Penerapan (Surabaya: Kata Pena, 2016), 68.

${ }_{28}$ Sugiyono, Metode Penelitian Kuantitatif, Kualitatif, Dan RnD (Bandung: ALFABETA, 2016), 7.

29 Mengenai PTK, baca; Agung Prihantoro dan Fattah Hidayat, "Melakukan Penelitian Tindakan Kelas," Ulumuddin : Jurnal Ilmu-ilmu Keislaman 9, no. 1 (2019): $49-60$, 


\section{Analisis Deskriptif}

Setelah data dikumpulkan, peneliti mendeskripsikan data data tersebut sebagai berikut:

1) Religiusitas

\section{Statistics}

Religiusitas (Y)

\begin{tabular}{|l|r|}
\hline N $\quad$ Valid & 114 \\
Mean & $\mathrm{O}$ \\
Median & 282.6667 \\
& 283.000 \\
Mode & $\mathrm{O}$ \\
Minimum & 308.00 \\
Maximum & 239.00 \\
\hline
\end{tabular}

Dari tabel data diatas dengan 114 responden, diketahui bahwa variabel religiusitas mempunyai mean 282.6667, median 283.00oo, dan modus 308.00. kemudian data tersebut mempunyai nilai minimal 239.00 dan nilai maksimal 317.00

Kemudian untuk penyajian tabel distribusi frekuensi dengan menggunakan rumus Sturgess: $(\mathrm{BK})=1+3.3 \log$ n. ${ }^{30}$ dengan hasil sebagai berikut:

\section{Tabel Distribusi Frekuensi}

\begin{tabular}{|c|c|c|c|}
\hline No & Skor & $\begin{array}{c}\text { frekuensi } \\
\text { Absolut (f) }\end{array}$ & $\begin{array}{c}\text { Frekuensi Relatif } \\
(\%)\end{array}$ \\
\hline 1 & $239-248$ & 4 & $4 \%$ \\
\hline 2 & $249-258$ & 6 & $5 \%$ \\
\hline 3 & $259-268$ & 18 & $16 \%$ \\
\hline 4 & $269-278$ & 20 & $18 \%$ \\
\hline 5 & $279-288$ & 22 & $19 \%$ \\
\hline 6 & $289-298$ & 18 & $16 \%$ \\
\hline 7 & $299-308$ & 19 & $17 \%$ \\
\hline 8 & $309-318$ & 7 & $6 \%$ \\
\hline \multicolumn{2}{|c|}{ Jumlah } & 114 & $100 \%$ \\
\hline
\end{tabular}

3o Kadir, Statistika Terapan (Jakarta: Rajawali Press, 2016). 


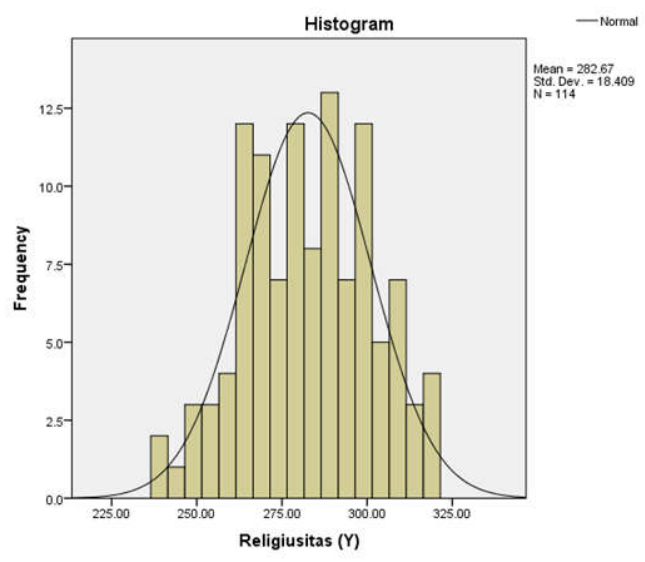

2) hidden curriculum

\section{Statistics}

hidden curriculum (X1)

\begin{tabular}{|l|r|}
\hline N $\quad$ Valid & 114 \\
& Missing \\
Mean & $\mathrm{O}$ \\
Median & 133.0614 \\
Mode & 131.5000 \\
Minimum & 148.00 \\
Maximum & 86.00 \\
\hline
\end{tabular}

Dari tabel data diatas dengan 114 responden, diketahui bahwa variabel hidden curriculum mempunyai mean 133.0614, median 131.5000, dan modus 148.oo. Kemudian data tersebut mempunyai nilai minimal 86.0o dan nilai maksimal 162.00.

Kemudian untuk penyajian tabel distribusi frekuensi dengan menggunakan rumus Sturgess: $(B K)=1+3.3 \log n, 3^{1}$ dengan hasil sebagai berikut:

Tabel Distribusi Frekuensi

\begin{tabular}{|c|c|c|c|}
\hline No & Skor & $\begin{array}{c}\text { frekuensi } \\
\text { Absolut (f) }\end{array}$ & $\begin{array}{c}\text { Frekuensi Relatif } \\
(\%)\end{array}$ \\
\hline 1 & $86-95$ & 2 & $2 \%$ \\
\hline 2 & $96-105$ & 2 & $2 \%$ \\
\hline 3 & $106-115$ & 9 & $8 \%$ \\
\hline 4 & $116-125$ & 26 & $23 \%$ \\
\hline 5 & $126-135$ & 25 & $22 \%$ \\
\hline 6 & $136-145$ & 18 & $16 \%$ \\
\hline 7 & $146-155$ & 20 & $18 \%$ \\
\hline 8 & $156-165$ & 12 & $11 \%$ \\
\hline \multicolumn{2}{|c|}{ Jumlah } & 114 & $100 \%$ \\
\hline
\end{tabular}

\footnotetext{
${ }^{31}$ Ibid., 25-26
} 


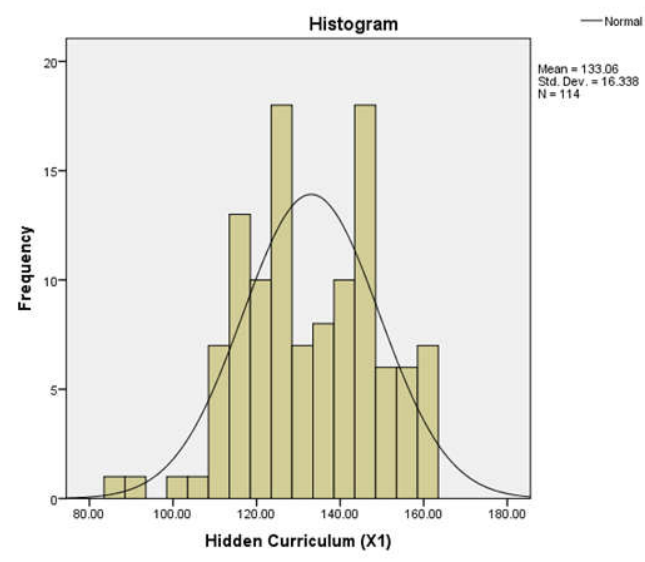

3) Disiplin

\section{Statistics}

Disiplin (X2)

\begin{tabular}{|l|r|}
\hline N $\quad$ Valid & 114 \\
& Missing \\
Mean & $\mathrm{O}$ \\
Median & 48.6404 \\
Mode & 48.0000 \\
Minimum & 44.00 \\
Maximum & 34.00 \\
\hline
\end{tabular}

Dari tabel data diatas dengan 114 responden, diketahui bahwa variabel religiusitas mempunyai mean 48.6404, median 48.00oo, dan modus 44.00. kemudian data tersebut mempunyai nilai minimal 34.00 dan nilai maksimal 60.00.

Kemudian untuk penyajian tabel distribusi frekuensi dengan menggunakan rumus Sturgess: $(\mathrm{BK})=1+3 \cdot 3 \log n .3^{2}$ dengan hasil sebagai berikut:

Tabel Distribusi Frekuensi

\begin{tabular}{|c|c|c|c|}
\hline No & Skor & $\begin{array}{c}\text { frekuensi } \\
\text { Absolut (f) }\end{array}$ & $\begin{array}{c}\text { Frekuensi Relatif } \\
\text { (\%) }\end{array}$ \\
\hline 1 & $34-36$ & 4 & $4 \%$ \\
\hline 2 & $37-39$ & 5 & $4 \%$ \\
\hline 3 & $40-42$ & 8 & $7 \%$ \\
\hline 4 & $43-45$ & 21 & $18 \%$ \\
\hline 5 & $46-48$ & 21 & $18 \%$ \\
\hline 6 & $49-51$ & 15 & $13 \%$ \\
\hline 7 & $52-54$ & 19 & $17 \%$ \\
\hline 8 & $55-57$ & 10 & $9 \%$ \\
\hline 9 & $58-60$ & 11 & $10 \%$ \\
\hline
\end{tabular}

32 Ibid., 25-26 


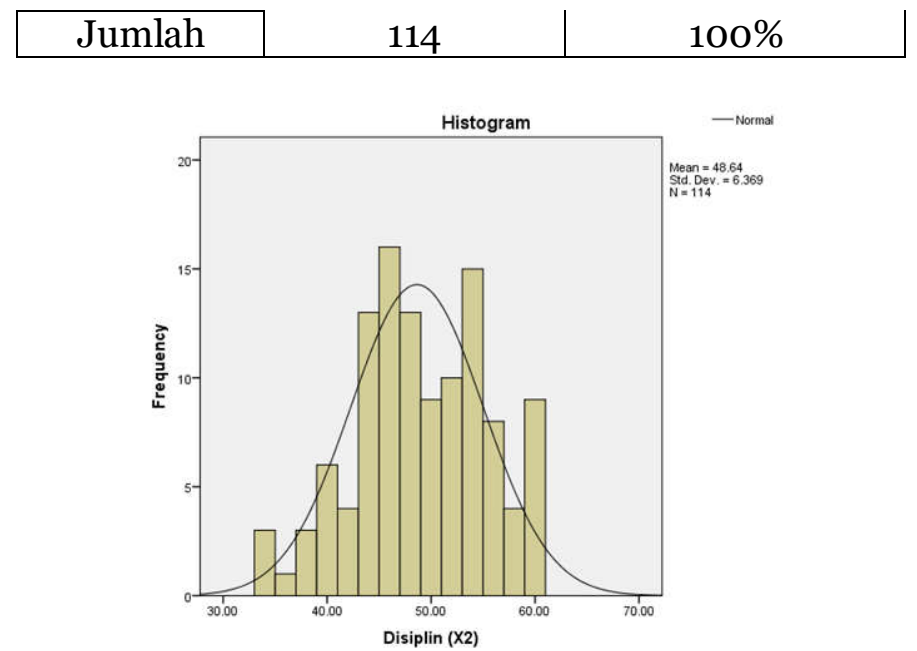

\section{Uji Persyaratan Analisis}

Uji prasyarat yang digunakan dalam penelitian ini uji Normalitas. Hasil pengujian normalitas data variabel religisuitas didapat nilai signifikansi $0.186>0.05$. Variabel hidden curriculum diperoleh nilai signifikansi sebesar $0.074>0.05$. sedangkan uji normalitas variabel disiplin diperoleh nilai Signifikansi $0.200>0.05$. berdasarkan hasil uji normalitas data dari ketiga variabel tersebut didapat bahwa data dari ketiga variabel tersebut berdistribusi normal.

\section{Uji Hipotesis}

Hasil pengujian hipotesis penelitian ini adalah sebagai berikut:

1) Uji Persamaan Persamaan Regresi Parsial

Coefficients ${ }^{a}$

\begin{tabular}{|c|c|c|c|c|c|c|c|c|}
\hline \multirow[b]{2}{*}{ Model } & \multicolumn{2}{|c|}{$\begin{array}{c}\text { Unstandardized } \\
\text { Coefficients }\end{array}$} & $\begin{array}{c}\text { Standardized } \\
\text { Coefficients }\end{array}$ & \multirow[b]{2}{*}{$\mathrm{T}$} & \multirow[b]{2}{*}{ Sig. } & \multicolumn{3}{|c|}{ Correlations } \\
\hline & B & $\begin{array}{l}\text { Std. } \\
\text { Error }\end{array}$ & Beta & & & $\begin{array}{l}\text { Zero- } \\
\text { order }\end{array}$ & Partial & Part \\
\hline 1 (Constant) & 194.872 & 12.027 & & 16.203 & .000 & & & \\
\hline hidden & & & & & & & & \\
\hline curriculum & .388 & .149 & .344 & 2.604 & .010 & .552 & .240 & .203 \\
\hline (X1) & & & & & & & & \\
\hline Disiplin (X2) & .743 & .382 & .257 & 1.944 & .054 & .536 & .181 & .151 \\
\hline
\end{tabular}

Diketahui nilai untuk pengaruh X1 terhadap Y adalah nilai t hitung 2.604 dan sig $(p$-value $)=0.010 / 2=0.005<0.05$, sehingga disimpulkan Ho ditolak dan Ha diterima yang berarti terdapat pengaruh X1 terhadap Y. 
Pengaruh X2 terhadap Y adalah nilai t hitung 1.944 dan sig ( $\mathrm{p}$-value) $0.057 / 2=0.027<0.05$, maka Ho ditolak yang berarti terdapat pengaruh $\mathrm{X} 2$ terhadap Y.

2) Uji Signifikansi Persamaan Regresi Ganda

\begin{tabular}{|ll|r|r|r|r|r|}
\hline \multicolumn{1}{|c|}{ ANOVA $^{\mathbf{a}}$} \\
\hline 1 & Sum of Squares & \multicolumn{1}{|c|}{ Df } & Mean Square & \multicolumn{1}{c|}{ F } & \multicolumn{1}{c|}{ Sig. } \\
& Regression & 12562.796 & 2 & 6281.398 & 27.095 & .000 $^{\mathrm{b}}$ \\
& Residual & 25732.537 & 111 & 231.825 & & \\
& Total & 38295.333 & 113 & & & \\
\hline
\end{tabular}

Diketahui nilai signifikansi untuk pengaruh X1 dan X2 secara simultan terhadap Y adalah sebesar $0.000<0.05$ maka Ho ditolak yang berarti terdapat pengaruh X1 dan X2 secara simultan terhadap Y.

3) Uji Signifikansi Koefisien Korelasi Ganda

\begin{tabular}{|l|l|r|r|r|r|r|r|r|r|}
\hline & & & & \multicolumn{5}{|c|}{ Change Statistics } \\
\cline { 6 - 10 } Model & $\mathrm{R}$ & Square & $\begin{array}{c}\text { Adjusted R } \\
\text { Square }\end{array}$ & $\begin{array}{c}\text { Std. Error of } \\
\text { the Estimate }\end{array}$ & $\begin{array}{c}\text { R Square } \\
\text { Change }\end{array}$ & $\begin{array}{c}\mathrm{F} \\
\text { Change }\end{array}$ & df1 & df2 & $\begin{array}{c}\text { Sig. F } \\
\text { Change }\end{array}$ \\
\hline 1 & $.573^{\mathrm{a}}$ & .328 & .316 & 15.22579 & .328 & 27.095 & 2 & 111 & .000 \\
\hline
\end{tabular}
a. Predictors: (Constant), Disiplin (X2), hidden curriculum (X1)

Diketahui koefisien korelasi ganda $\left(\mathrm{R}_{\mathrm{y} .12}\right)=0.573$ dan $\mathrm{F}$ hitung $(\mathrm{F}$ change $)=27.095$, serta $\mathrm{p}$-value $=0.000<0.05$. dengan demikian, korelasi antara $\mathrm{X} 1$ dan $\mathrm{X} 2$ dengan $\mathrm{Y}$ adalah signifikan. Sedangkan dilihat dari koefisien korelasi ganda $\left(\mathrm{R}_{\mathrm{y} .12}\right)=0.573$, Korelasi 0,573 termasuk kedalam korelasi sedang.33 koefisien determinasi ditunjukkan dengan mencari $\mathrm{R}$ Square $0.328(100 \%)=32.8$ mengandung makna bahwa $32.8 \%$ varabilitas variabel hidden curriculum (X1) dan disiplin (X2) terhadap religiusitas (Y). sehingga data disimpulkan bahwa pengaruh hidden curriculum dan disiplin terhadap religiusitas memberikan pengaruh sebesar sebesar $32.8 \%$.

4) Uji Signifikansi Korelasi Parsial

\begin{tabular}{|c|c|c|c|c|}
\hline \multicolumn{5}{|c|}{ Correlations } \\
\hline \multicolumn{3}{|c|}{ Control Variables } & Religiusitas (Y) & $\begin{array}{c}\text { hidden } \\
\text { curriculum } \\
(\mathrm{X} 1)\end{array}$ \\
\hline \multirow[t]{2}{*}{$\begin{array}{l}\text { Disiplin } \\
\text { (X2) }\end{array}$} & Religiusitas (Y) & $\begin{array}{l}\text { Correlation } \\
\text { Significance (1-tailed) } \\
\text { Df }\end{array}$ & $\begin{array}{r}1.000 \\
. \\
0\end{array}$ & $\begin{array}{r}.240 \\
.005 \\
111 \\
\end{array}$ \\
\hline & hidden curriculum (X1) & $\begin{array}{l}\text { Correlation } \\
\text { Significance (1-tailed) }\end{array}$ & $\begin{array}{l}.240 \\
.005\end{array}$ & 1.000 \\
\hline
\end{tabular}

33 M. Subana Sudrajat, Dasar Dasar Penelitian Ilmiah (Bandung: Pustaka Setia, 2005), 183. 
Diketahui koefisien korelasi parsial $\mathrm{R}_{\mathrm{y} 1.2}=0.240$ dan $\operatorname{sig}(\mathrm{p}$-value) $=$ $0.005<0.05$, dengan demikian koefisien korelasi antara X1 dan Y dengan mengontrol variabel X2 adalah signifikan. Koefisien korelasi $\mathrm{R}_{\mathrm{y} 1.2}=0.240$, korelasi 0.240 termasuk kedalam korelasi yang rendah namun tetap berpengaruh.34 Sedangkan koefisien determinasi ditunjukkan dengan mencari R Square yaitu $\left(0.240^{2} \times 100 \%=0.057 \times 100 \%=5,7 \%\right)$ yang mengandung makna bahwa $5.7 \%$ varabilitas variabel hidden curriculum (X1) dan religiusitas (Y) dengan mengontrol variabel disiplin (X2). sehingga data disimpulkan bahwa pengaruh hidden curriculum terhadap religiusitas memberikan pengaruh sebesar sebesar 5.7\%.

Correlations

\begin{tabular}{|lll|r|r|}
\hline \multirow{2}{*}{ Control Variables } & & Religiusitas (Y) & $\begin{array}{c}\text { Disiplin } \\
\text { (X2) }\end{array}$ \\
\hline hidden curriculum (X1) & Religiusitas (Y) & Correlation & 1.000 & .181 \\
& & Significance (1-tailed) &. & .027 \\
& & Df & 0 & 111 \\
\cline { 2 - 5 } & Disiplin (X2) & Correlation & .181 & 1.000 \\
& Significance (1-tailed) & .027 &. \\
& Df & 111 & 0 \\
\hline
\end{tabular}

Diketahui koefisien korelasi parsial $\mathrm{R}_{\mathrm{y} .2 .1}=0.181$ dan sig $(\mathrm{p}$-value) $=$ $0.027<0.05$, dengan demikian koefisien korelasi antara X2 dan Y dengan mengontrol variabel X1 adalah signifikan. Koefisien korelasi $\mathrm{R}_{\mathrm{y1} .2}=181$, korelasi 0.181 termasuk kedalam korelasi yang rendah sekali namun tetap berpengaruh.35 Sedangkan koefisien determinasi ditunjukkan dengan mencari R Square yaitu (0.1812 x 100\% = $0.032 \times 100 \%=3.2 \%)$ yang mengandung makna bahwa 3.2 \% varabilitas variabel disiplin (X2) dan religiusitas (Y) dengan mengontrol variabel hidden curriculum (X1). sehingga data disimpulkan bahwa pengaruh disiplin terhadap religiusitas memberikan pengaruh sebesar sebesar 3.2\%.

\section{E. Pembahasan}

1. Pengaruh hidden curriculum terhadap religiusitas siswa SMPN 1 Mlarak Ponorogo tahun 2019-2020.

Berdasarkan hasil analisis, penelitian ini menunjukkan adanya pengaruh positif hidden curriculum terhadap religiusitas siswa SMPN 1 


\section{Pengaruh Hidden Curriculum dan Disiplin Terhadap}

Religiusitas Siswa SMPN 1 Mlarak Ponorogo

Mlarak Ponorogo tahun ajaran 2019-2020 berdasarkan nilai signifikasi $0.010 / 2=0.005<0.05$. hasil penelitian ini sejalan dengan pendapat Oemar Hamalik kurikulum tersembunyi adalah kurikulum yang tidak direncanakan dan tidak termasuk ke dalam kurikulum sekolah, tetapi memiliki pengaruh penting dalam kehidupan siswa.36. Hal ini diperkuat dengan teori Allan G. Glattron, bahwa hidden curriculum memberi efek, berpengaruh dan memberi perubahan nilai, presepsi, dan perilaku siswa. 37 Dan peneliti sudah membuktikan adanya pengaruh yang positif dan signifikan antara hidden curriculum terhadap religiusitas siswa SMPN 1 Mlarak Ponorogo tahun ajaran 2019-2020.

2. Pengaruh disiplin terhadap religiusitas siswa SMPN 1 Mlarak Ponorogo tahun 2019-2020.

Berdasarkan hasil analisis, penelitian ini menunjukkan adanya positif disiplin terhadap religiusitas siswa SMPN 1 Mlarak Ponorogo tahun ajaran 2019-2020 berdasarkan nilai signifikansi 0.057/2=0.027<0.05. hasil ini sejalan dengan pendapat Yaumi bahwa disiplin adalah tindakan yang menujukkan perilaku tertib dan patuh pada berbagai ketentuan dan peraturan yang berlaku. ${ }^{38}$ Begitu juga pendapat Stevenson menghasilkan sesuatu dengan seluruh daya dan upaya tanpa adanya suruhan dalam melakukannya.39 Hal tersebut disimpulkan disiplin merupakan serangkaian perilaku yang dilakukan seseorang yang menunjukkan kepatuhan dan ketaatan terdahap perilaku dan tata tertib yang muncul dari dorongan yang ada dalam dirinya untuk mencapai tujuan yang diinginkan. Maka, peneliti dapat membuktikan bahwa terdapat pengaruh antara disiplin terhadap religiusitas siswa SMPN 1.

3. Pengaruh hidden curriculum dan disiplin terhadap religiusitas siswa

SMPN 1 Mlarak Ponorogo tahun 2019-2020.

Berdasarkan hasil analisis, penelitian ini menunjukkan adanya pengaruh positif hidden curriculum dan disiplin secara simultan terhadap religiusitas siswa SMPN 1 berdasarkan nilai signifikansi $0.000<0.05$. Hal

\footnotetext{
${ }^{36}$ Hamalik, Dasar Dasar Pengembangan, 23.

37 Caswita, The Hidden Curriculum, 45.

38 Yaumi, Pendidikan Karakter, 92.

39 Ibid.
} 
ini sejalan dengan pendapat Hamalik kurikulum tersembunyi adalah kurikulum yang tidak direncanakan dan tidak termasuk ke dalam kurikulum sekolah, tetapi memiliki pengaruh penting dalam kehidupan siswa. Begitu pentingnya peran disiplin terhadap religiusitas siswa sebagai usaha yang timbul dalam diri seseorang berupa pengontrolan diri menghasilkan sesuatu dengan seluruh daya dan upaya tanpa adanya suruhan dalam melakukannya. Dengan demikian adanya hidden currciculum yang dibarengi dengan disiplin akan mempengaruhi religiusitas siswa. Dan peneliti sudah membuktikan adanya pengaruh yang positif dan signifikan antara hidden curriculum dan disiplin terhadap religiusitas siswa SMPN 1 Mlarak Ponorogo tahun ajaran 2019-2020.

\section{F. Kesimpulan}

Berdasarkan hasil penelitian di atas, kesimpulan dari dapat dirumuskan. Pertama, terdapat pengaruh hidden curriculum terhadap religiusitas siswa. Kedua; terdapat pengaruh disiplin terhadap religiusitas siswa. Ketiga, terdapat pengaruh hidden curriculum dan disiplin secara bersama-sama terhadap religiusitas siswa SMPN 1.

Implikasi dari hasil penelitian ini adalah pentingnya pengembangan hidden curriculum dan disiplin yang baik pada SMP, sehingga tingkat religiusitas siswa akan meningkat. Saran bagi peneliti selanjutnya, diharapkan dapat mengembangkan penelitian ini dengan menambah variabel yang belum diteliti dalam penelitian ini.

\section{Daftar Pustaka}

Ancok, Djamaluddin, and Fuad Nashori Suroso. Psikologi Islam Solusi Islam Atas Problem Problem Psikologi. Yogyakarta: Pustaka Pelajar, 1995.

Arikunto, Suharsimi. Managemen Penelitian. Jakarta: Rineka Cipta, 2001. Caswita. The Hidden Curriculum: Studi Pembelajaran PAI Di Sekolah. Yogyakarta: Leutikaprio, 2013.

Diana, Feri Sulis, Setyorini, and Sapto Irawan. "Pengaruh Nilai Pendidikan Karakter Terhadap Disiplin Siswa Kelas XI SMK Islam Sudirman Tahun Ajaran 2018/2019." Jurnal Psikologi Konseling 12, no. 1 (2019): 373-386.

Fatihah, Nurul, and Difla Nadjih. "Hubungan Pendidik Dan Terdidik Dalam Al-Quran.” Ulumuddin: Jurnal Ilmu-ilmu Keislaman 7, no. 2 (2017): 73-86.

Hamalik, Oemar. Dasar Dasar Pengembangan Kurikulum. Bandung: 
Remaja Rosda Karya, 2009.

Kadir. Statistika Terapan. Jakarta: Rajawali Press, 2016.

Kurinasih, Imas, and Berlin Sani. Implementasi Kurikulum 2013 Konsep Dan Penerapan. Surabaya: Kata Pena, 2016.

Musaropah, Umi. "Pendidikan Kebangsaan Dalam Pesantren Perspektif Abdul Wahid Hasyim.” Ulumuddin: Jurnal Ilmu-ilmu Keislaman 9, no. 1 (2019): 1-22.

Nugroho, Taufik. "Ideologi Pendidikan Pondok Pesantren Al-Islam Tenggulun Solokuro Lamongan." Ulumuddin: Jurnal Ilmu-ilmu Keislaman 9, no. 2 (2020): 97-112.

- - - "Pendidikan Karakter Dalam Al-Qur'an (Studi Tafsir Pendidikan Surat Luqman).”

Palupi, Atika Oktaviana. "Pengaruh Religusitas Terhadap Kenakalan Remaja Pada Siswa Kelas VIII SMP Negeri o2 Slawi Kabupaten Tegal.” Universitas Negeri Semarang, 2013.

Pratiwi, Esti Rahma. "Pengaruh Kurikulum Tersembunyi (Hidden Curriculum) Terhadap Pembentukan Karakter Siswa Kelas VIII Di SMP IT Masjid Syuhada' Kotabaru Yogyakarta.” UIN Sunan Kalijaga, 2016.

Prihantoro, Agung, and Fattah Hidayat. "Melakukan Penelitian Tindakan Kelas.” Ulumuddin : Jurnal Ilmu-ilmu Keislaman 9, no. 1 (2019): 49-6o.

Pusat Kurikulum Kemendiknas. Pendidikan Budaya Dan Karakter Bangsa. Jakarta: Kemendiknas, 2010.

Ratmaningsih, Neiny. Pendidikan Pancasila Dan Kewarganegaraan Untuk SMU Kelas 1. Bandung: Grafindo Media Pratama, 2000.

Rosyada, Dede. Paradigma Pendidikan Demokratis. Jakarta: Kencana Prenada Media Group, n.d.

Sudarsono. Kenakalan Remaja. Jakarta: Rineka Cipta, 2008.

Sudrajat, M. Subana. Dasar Dasar Penelitian Ilmiah. Bandung: Pustaka Setia, 2005.

Sugiyono. Metode Penelitian Kuantitatif, Kualitatif, Dan RnD. Bandung: ALFABETA, 2016.

Sulistiyo, Rozib. "Penguatan Peran Guru Pendidikan Agama Islam Dalam Penanaman Akhlak Di Sekolah." Ulumuddin: Jurnal Ilmu-ilmu Keislaman 6, no. 1 (2016): 1-10.

Syarifah. Managemen Pengelolaan Lembaga Pendidikan. Ponorogo: Unida Gontor Press, 2018.

Widiyanta, Ari. "Sikap Terhadap Lingkungan Dan Religiusitas." Jurnal Pemikiran Dan Penelitian Psikologi 1, no. 2 (2005).

Yaumi, Muhammad. Pendidikan Karakter, (Landasan, Pilar, Dan Implementasi). Jakarta: Kencana, 2014.

Zainuddin, Din. Pendidikan Budi Pekerti Dalam Perspektif Islam. Jakarta: Al Mawardi Prima, 2005. 